Gut, 1974, 15, 703-705

\title{
Effect of calcitonin on the formation, composition, and enzymatic activity of the hepatic bile in guinea pigs
}

\author{
A. TARNAWSKI, J. BOGDAE, K. DURA, Z. MARSZAEEK, AND \\ A. JEDRYCHOWSKI
}

From the Department of Gastroenterology, Medical Academy, Cracow, and the Department of Surgical Gastroenterology, Medical Academy, Cracow, Poland

SUMMARY Porcine calcitonin given to guinea pigs in doses causing hypocalcaemia and hypophosphataemia decreased the bilirubin concentration and increased the activity of gamma glutamyl transpeptidase (GGTP) in the hepatic bile. Calcitonin had no effect on bile flow, its pH, electrolyte composition including calcium, or on the concentration of protein, glucose, cholesterol, nonprotein nitrogen (NPN), and bile acids. It also did not affect the activities of alanine aminotransferase (AIAT) and alkaline phosphatase (AP) in the hepatic bile. Calcitonin increased the calcium content in the liver.

Calcitonin exerts an inhibitory effect on various secretory systems of the gastrointestinal tract in man and in animals reducing basal and stimulating gastric acid secretion (Hesch, Hüfner, Hasenhager, and Creutzfeld, 1971; Hotz, Widmaier, Minne, and Ziegler, 1971; Doepfner and Ohnhaus, 1972; Hüfner, Hesch, Schmidt, Hasenjäger, Winckler, Creutzfeldt, and Paschen, 1972; Case, 1973) and also stimulating pancreatic secretion (Hüfner et al, 1972; Doepfner and Ohnhaus, 1972; Case, 1973).

Although these gastrointestinal effects of calcitonin are well documented there is little information concerning the influence of this hormone on the flow and composition of the hepatic bile. This problem seems to be interesting for at least two reasons: first, the possibility of interaction of calcitonin with gastrointestinal hormones (Hesch, Hüfner, Schmidt, Winckler, Siewert, and Creutzfeldt, 1972), and second, the effect of calcitonin on calcium metabolism (Hirsch and Munson, 1969; Pak, 1971; Bijvoet, Van der Sluys Veer, Greven, and Schellekens, 1972). The role of calcium in gastrointestinal secretion has been reviewed elsewhere (Case, 1973) and the dependence of bile formation on calcium has also been documented (Graf, Kaschnitz, Korn, and Peterlik, 1973).

The present study was undertaken with the object of investigating the action of calcitonin on the

Received for publication 8 May 1974. volume and composition of the hepatic bile in guinea pigs, especially in relation to calcium and inorganic phosphate concentration as well as to the activity of certain enzymes in the bile. In order to obtain more detailed information, some of the components were studied simultaneously in blood plasma and liver tissue.

\section{Materials and Methods}

The experiments were carried out on 20 guinea pigs with an average weight of $343.5 \mathrm{~g}$, divided into two groups of 10 each. Under ether anaesthaesia the cystic duct was tied and the common bile duct cannulated with a polyethylene tube of $0.8 \mathrm{~mm}$ inner diameter. The first group received calcitonin (Calcitare) intramuscularly in a single dose of 20 MRC U per animal in $0.25 \mathrm{ml}$ of gelatin diluent. The second group received gelatin diluent only and served as controls. All animals were kept in restraining cages and the bile was collected for 180 minutes after the injection of calcitonin or diluent. After this period, blood was obtained by cardiac puncture. The animals were then killed and specimens of liver tissue were excised, weighed, and homogenized in $10 \mathrm{ml}$ of saline using an electric homogenizor.

The total volume of bile secreted within 180 minutes, $\mathrm{pH}$, concentration of protein, cholesterol, bicarbonates, chlorides, sodium, potassium, and 


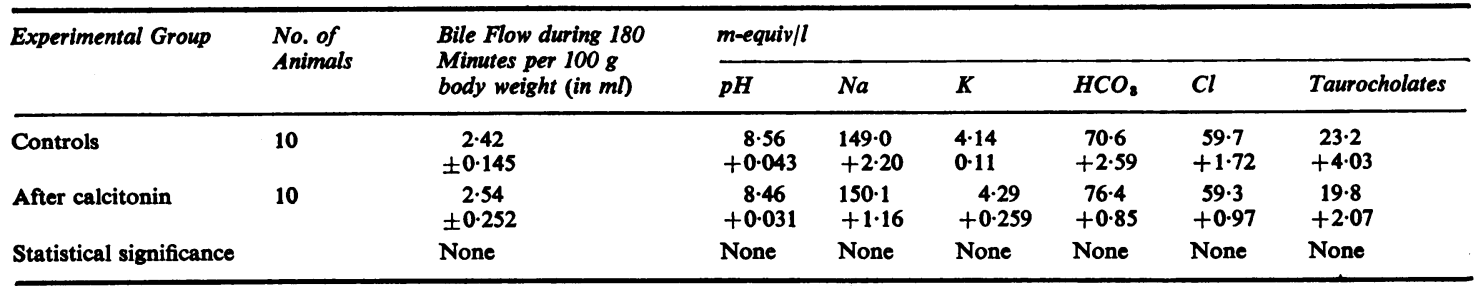

Table I Flow rate, $\mathrm{pH}$, and electrolyte composition of bile ${ }^{1}$

${ }^{1}$ Mean \pm SEM

\begin{tabular}{|c|c|c|c|c|c|c|c|c|}
\hline \multirow[t]{2}{*}{ Experimental Group } & \multirow[t]{2}{*}{ No. of Animals } & \multicolumn{4}{|l|}{ m-equiv/l } & \multicolumn{3}{|c|}{$m g / 100 \mathrm{ml}$} \\
\hline & & $\mathrm{Ca}$ & Inorganic $P$ & Protein & $N P N$ & Glucose & Cholesterol & Bilirubin \\
\hline Controls & 10 & $\begin{array}{c}1.45 \\
\pm 0.098\end{array}$ & $\begin{array}{r}6.43 \\
\pm 1.63\end{array}$ & $\begin{array}{r}66.6 \\
\pm 10.59\end{array}$ & $\begin{array}{c}41.6 \\
\pm 3.48\end{array}$ & $\begin{array}{c}20.0 \\
\pm 4.27\end{array}$ & $\begin{array}{c}21.0 \\
\pm 3.06\end{array}$ & $\begin{array}{r}1.50 \\
\pm 0.20\end{array}$ \\
\hline After calçitonin & 10 & $\begin{array}{c}1.43 \\
\pm 0.097\end{array}$ & $\begin{array}{r}4 \cdot 12 \\
\pm 1 \cdot 14\end{array}$ & $\begin{array}{r}60.0 \\
\pm 21.8\end{array}$ & $\begin{array}{c}38 \cdot 3 \\
\pm 3 \cdot 15\end{array}$ & $\begin{array}{c}19.5 \\
\pm 6.61\end{array}$ & $\begin{array}{c}28.6 \\
\pm 3.61\end{array}$ & $\begin{array}{r}0.93 \\
\pm 0.07\end{array}$ \\
\hline
\end{tabular}

Table II Concentration of components in bile ${ }^{1}$

'Mean \pm SEM

\begin{tabular}{|c|c|c|c|c|}
\hline \multirow[t]{2}{*}{ Experimental Group } & \multirow[t]{2}{*}{ No. of Animals } & \multicolumn{3}{|c|}{ Enzyme Activity $(m U / m l)$} \\
\hline & & $A 1 A T$ & $\boldsymbol{A P}$ & GGTP \\
\hline After calcitonin & 10 & $\begin{array}{r}0.37 \\
\pm 0.18\end{array}$ & $\begin{array}{r}3.92 \\
\pm 1.73\end{array}$ & $\begin{array}{r}6.20 \\
\pm 0.60\end{array}$ \\
\hline
\end{tabular}

Table III Average of enzyme activities in bile

the activities of AP, GGTP, and A1AT were assayed by the same methods as reported previously (Kirchmayer, Tarnawski, Drożdż, and Cicheka, 1972). The concentration of calcium was determined by complexometry, glucose by the method of Nelson and Somogyi, while inorganic phosphate, NPN, and bilirubin concentration were measured using routine laboratory micromethods. The results thus obtained were statistically analysed using Student and Welch t tests.

\section{Results}

The average bile volume, $\mathrm{pH}$, and concentration of the investigated components are given in tables $I$ and II. In table III the activities of A1AT, AP, and GGTP in the bile are shown. The concentration of calcium and inorganic phosphates in plasma are presented in table IV. Table V shows the values for calcium and inorganic phosphate concentration and GGTP activity in the liver.

As can be seen from the tables, no statistically significant changes were observed after calcitonin in the volume, $\mathrm{pH}$, or any of the analysed compo-

\begin{tabular}{lccc}
\hline $\begin{array}{l}\text { Experimental } \\
\text { Group }\end{array}$ & $\begin{array}{c}\text { No. of } \\
\text { Animals }\end{array}$ & \multicolumn{2}{c}{ m-equiv/l } \\
\cline { 2 - 4 } & & $C a$ & Inorganic $P$ \\
\hline Controls & 10 & 5.28 & 5.06 \\
& & \pm 0.12 & \pm 0.61 \\
After calcitonin & 10 & 3.54 & 3.22 \\
Statistical & & \pm 0.195 & \pm 0.36 \\
significance & & $P<0.01$ & $P<0.05$ \\
\hline
\end{tabular}

Table IV Calcium and inorganic phosphorus concentrations in blood plasma ${ }^{1}$

${ }^{2}$ Mean \pm SEM 


\begin{tabular}{|c|c|c|c|c|}
\hline \multirow[t]{2}{*}{ Experimental Group } & \multirow[t]{2}{*}{ No. of Animals } & \multicolumn{2}{|c|}{$\mu$-equiv per $\mathrm{g}$ of Fresh Tissue } & \multirow{2}{*}{$\frac{(m U \text { per } g)}{\text { Fresh Tissue GGTP }}$} \\
\hline & & Calcium & Inorganic Phosphorus & \\
\hline Controls & 10 & $\begin{array}{r}1.79 \\
\pm 0.19\end{array}$ & $\begin{array}{r}43 \cdot 0 \\
\pm 3 \cdot 1\end{array}$ & $\begin{array}{c}10900 \\
\pm 1390\end{array}$ \\
\hline After calcitonin & 10 & $\begin{array}{r}3 \cdot 10 \\
\pm 0 \cdot 22\end{array}$ & $\begin{array}{r}46.6 \\
\pm 2.7\end{array}$ & $\begin{array}{r}12970 \\
\pm 1500\end{array}$ \\
\hline Statistical significance & & $P<0.05$ & None & None \\
\hline
\end{tabular}

Table V Concentrations of calcium and inorganic phosphorus and activity of GGTP in liver ${ }^{1}$

${ }^{1}$ Mean \pm SEM

nents of the bile except a decrease in bilirubin concentration and an increase in GGTP activity in the bile. In the liver tissue an increase in GGTP activity was observed.

\section{Discussion}

The calcitonin used in this experiment caused a significant decrease in the calcium and inorganic phosphate concentration in the blood plasma, which shows that guinea pigs are sensitive to porcine calcitonin. These results are in accordance with the observation of Talmage and Anderson (1972), who obtained a similar effect after calcitonin in rats.

Hypocalcaemia of such a range as in our experiment has no significant effect on the bile flow in guinea pigs, though the data of Graf et al (1973) indicate that hypocalcaemia markedly changes the secretion of the bile in rats. This discrepancy may be due to the different species of animals and various degrees of hypocalcaemia.

The decrease in plasma calcium and inorganic phosphate levels after calcitonin was not accompanied by any significant changes in the concentration of these components in the bile. This may suggest that the 'bile pole' of the hepatocyte does not participate in the changes of calcium and phosphate metabolism evoked by calcitonin

The decrease in bilirubin concentration in the bile after calcitonin was not accompanied by any significant changes in bile volume nor in the concentration of other components. This may suggest that calcitonin selectively inhibits the transport of bilirubin into the bile, probably by inhibition of enzymes involved in this transport.

The increase in GGTP activity in the bile after calcitonin may be the result of induction of this enzyme in the liver or its enhanced excretion by hepatocytes into the bile or both. The first possibility is supported by a simultaneously observed increase in GGTP activity in the liver after calcitonin. The rise of GGTP activity in the bile after calcitonin affords further evidence that the activity of some 2 enzymes excreted with the bile is under hormonal influence (Kirchmayer et al, 1972; Świerczek, 1972).

Calcitonin causes an increase in calcium concentration in the liver tissue. This fact is in accordance with our previous observation and supports the hypothesis that calcitonin affects the distribution of calcium in the tissues of the gastrointestinal tract.

Calcitonin (Calcitare) was kindly supplied by the Armour Pharmaceutical Company.

\section{References}

Bijvoet, O. L. M., Van der Sluys Veer J., Greven, H. M., and Schellekens, A. P. M. (1972). Influence of calcitonin on renal excretion of sodium and calcium. In Calcium, Parathyroid Hormone and the Calcitonin (Int. Congr. Ser., no. 143) edited by R. V. Talmage nad P. K. Munson, pp. 284-298. Excerpta Medica, Amsterdam.

Case, R. M. (1973). Calcium and gastrointestinal secretion. Digestion, 8, 269-288.

Doepfner, W. E. H., and Ohnhaus, E. E. (1972). Gastrointestinal effects of synthetic salmon-calcitonin in the cat. (Abstr.) Biol. Gastroent., 5, 456c.

Graf, J., Kaschnitz, R., Korn, P., and Peterlik, M. (1973). Dependence of bile formation on calcium. (Abstr.) Digestion, 8, 515.

Hesch, R. D., Hüfner, M., Hasenhager, B., and Creutzfeld, W. (1971). Inhibition of gastric secretion by calcitonin in man. Horm. metab. Res., 3, 140-141.

Hesch, R. D., Hüfner, M., Schmidt, H., Winckler, K., Siewert, R., and Creutzfeldt, W. (1972). Calcitonin: further results on gastrointestinal effects. (Abstr.) Biol. Gastro-ent., 5, 457c.

Hirsch, P. F., and Munson, P. L. (1969). Thyrocalcitonin. Physiol. Rev., 49, 548-622.

Hotz, J., Widmaier, F., Minne, H., and Ziegler, R. (1971). Serum calcium and gastric secretion in chronic gastric fistula rat: influence of parathyroid hormone and calcitonin. Europ. $J$. clin. Invest., 1, 486-490.

Hüfner, M., Hesch, R. D., Schmidt, H., Hasenjäger, M., Winckler, K., Creutzfeldt, W., and Paschen, K. (1972). The gastrointestinal effects of calcitonin. (Abstr.) Acta. endocr. (Kbh.), Suppl. 159, 65.

Kirchmayer, S., Tarnawski, A., Drożdż, H., and Cichecka, K. (1972). Effect of cholecystokinin-pancreozymin and secretin on the volume, composition, and enzymatic activity of hepatic bile in rabbits. Gut, 13, 709-712.

Pak, C. Y. C. (1971). Parathyroid hormone and thyrocalcitonin: their mode of action and regulation. Ann. N.Y. Acad. Sci., $179,450-474$.

Swierczek, J. (1972). Secretion and biochemical properties of bile in functional thyroid disorders (in Polish) Folia med. (Cracoviensia), 14, 465-489.

Talmage, R. V., and Anderson, J. J. B. (1972). The effect of calcitonin on ${ }^{29} \mathrm{P}$ disappearance from plasma in parathyroidectomized and nephrectomized rats (1972). Proc. Soc. exp. Biol. (N.Y.), $141,982-985$. 